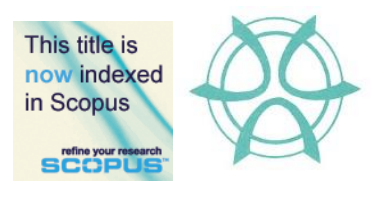

PLANNING MALAYSIA:

Journal of the Malaysian Institute of Planners

VOLUME 17 ISSUE 1 (2019), Page 149 - 159

\title{
TOTAL FACTOR PRODUCTIVITY CHANGE IN THE REIT INDUSTRY: THE CASE OF MALAYSIAN REITS DURING AND POST GLOBAL FINANCIAL CRISIS
}

\author{
Nor Nazihah Chuweni ${ }^{1}$, Ihsan Isik ${ }^{2} \&$ Andrea Blake ${ }^{3}$ \\ ${ }^{1}$ Faculty of Architecture, Planning and Surveying \\ UNIVERSITI TEKNOLOGI MARA, PERAK BRANCH, MALAYSIA \\ ${ }^{2}$ William G. Rohrer College of Business \\ ROWAN UNIVERSITY, USA \\ ${ }^{3}$ Science and Engineering Faculty \\ QUEENSLAND UNIVERSITY OF TECHNOLOGY, AUSTRALIA
}

\begin{abstract}
The paper examined productivity changes for the Malaysian Real Estate Investment Trust (M-REITs) using a non-parametric approach of Malmquist Productivity Index (MPI) of Data Envelopment Analysis (MPI-DEA). Data was attained from M-REIT annual reports, Thomson Reuters Datastream and Osiris via Bureau Van Dijk for 2007-2015. The non-parametric approach of MPI-DEA examined the Total Factor Productivity Change (TFPCH), Technological Change (TECHCH), Efficiency Change (EFFCH), Pure Technical Efficiency Change (PEFFCH) and Scale Efficiency Change (SECH) indices. On average, the M-REIT industry has faced $14.91 \%$ of productivity regress during 2007-2015 period, comprising $49.90 \%$ of efficiency increase and $33.40 \%$ technological regress. The decomposition of the productivity change index suggests that Malaysian REIT productivity changes were mainly due to efficiency change rather than technological change. These findings could help M-REIT managers to formulate ways to enhance their REIT productivity. The findings are also applicable to similar Shariah compliant real estate investment or socially responsible investment.
\end{abstract}

Keyword: Malmquist index; productivity, technology, efficiency, Malaysian REITs 
Nor Nazihah Chuweni, Ihsan Isik \& Andrea Blake

Total factor productivity change in the REIT industry: The case of Malaysian REIT during and post global financial crisis

\section{INTRODUCTION}

Global financial crisis began in 2007 with a crisis in the US subprime mortgage market and the situation getting worse with the bankruptcy of Lehman Brothers in 2008. While the collapse of large financial institutions was prevented by the interventions of national governments to bail out distress banks, stock markets still dropped worldwide. Malaysia was not an exception. Along with other countries, the impact of the crisis on Malaysia has been felt largely through contraction in demand of exports particularly when the economies of its major trading partners fell. The Kuala Lumpur Composite Index, which is the main index and market indicator in Malaysia, has experience a $45 \%$ drop in its value within the period of January to September 2008 (Angabini \& Wasiuzzaman, 2011). However, despite its severity on the economics, the financial crisis has not been studied yet in terms of its impact on the productivity growth, efficiency change, and the technological progress of REITs.

If confidence in the REIT industry is shaken, both local and global investors may leave the industry and the country, increasing the vulnerability of the real estate industry to subsequent shock. This study will be the first empirical investigation to examine and estimate the total factor productivity (TFP) for Malaysian REITs, using the non-parametric approach of Malmquist data envelopment analysis (DEA) from 2007 to 2015. The remainder of the paper unfolds as follows. Section 2 provides an overview of the review of the literature, followed by methodology and empirical design. Section 4 discusses the empirical findings, which highlight the productivity change of Malaysian REITs and the respective productivity and efficiency sources. Section 5 concludes the article and provides suggestions for future research.

\section{LITERATURE REVIEW}

While there has been extensive literature examining the efficiency and productivity in the mature market of the USA, the works on emerging market of Malaysian REITs are still under-researched. Previous works have applied various frontier techniques of estimation for the efficiency and productivity of these REITs. Topuz, Darrat and Shelor (2005) measured the technical, allocative and scale efficiency of US REIT from 1989 to 1999 with results showing that inefficiency was caused by a high level of input use instead of the choice of input mix. Similar approach of estimation of Malaysian Islamic REITs are conducted by Chuweni, Eves, Hoang, Isik and Hassan (2017). Their findings revealed that Malaysian REITs can reduce their input consumption by $35.8 \%$ without reducing output, implying significant potential for improvement. Isik and Topuz (2017) employed non-parametric approach of DEA approach on eleven-year dataset from the 1990s. The de novo REITs outperform the established REITs in all form of efficiency scores. The result suggest that these new REITs are 'born efficient' which are likely due to the REIT size, accessibility to finance and are rich with congenital experience. In another study, Topuz and Prather (2007) employed the Malmquist Index to measure the equity REIT efficiency and productivity change 
PLANNING MALAYSIA

Journal of the Malaysia Institute of Planners (2019)

for 1989 to 1999. Regardless of their size, REITs experienced increases in technical efficiency during 1994-1999 due to both managerial and scale efficiency. However, a significant level of technological regress leads to REIT productivity losses. However, none of these studies have critically addressed the productivity performance in the REIT industry, particularly in the emerging market of Malaysia during two different periods: during and post global financial crisis. This present study differs with the above studies in terms of data (Malaysian REITs from 2007 to 2015), approach (use of input/output variables) and foci (productivity change of Malaysian REITs).

\section{METHODOLOGY}

For this study, productivity change was measured using the input-oriented Malmquist Productivity Index (MPI). MPI, which was developed by Fare, Grosskopf and Lovell (1994), differentiates the shift production frontier (technological change) and the movement of REIT towards the frontier (efficiency change). The Malmquist index was constructed using the DEA software of DEAP version 2.1 by Coelli (1996). Grifell-Tatjé and Lovell (1996) highlighted three advantages of MPI over Fischer and Tornqvist indices. Firstly, MPI does not require price information for input and output prices. Secondly, MPI does not require restricted assumption (profit maximisation or cost minimisation) in its calculation. Thirdly, panel data allow the decomposition of productivity changes as a product of the effect of catch up to the frontier (efficiency change) and the frontier-shift effect (technological change). The main drawback is the need of a distance functions measurement, which could be resolved by using the DEA. Furthermore, Translog and Cobb-Douglass functions are prone to model sensitivity and functional stability (Topuz \& Isik, 2009).

MPI allows us to isolate the effect of catching up or falling behind to the frontier effect (efficiency change) from the effect of outward shift or regress in REIT technological frontier (technological change). In other words, Malmquist total factor productivity change index (TFPCH) is the product of efficiency change (EFFCH) and technological change (TECHCH) under the assumption of constant returns to scale (CRS). This decomposition allows us to identify the sources of productivity change in M-REIT. However, due to the imperfect market competition and regulatory restraints, REITs may operate at increasing return to scale (IRS) or decreasing return to scale (DRS), instead of operating at CRS. Therefore, when we relaxed the assumption of CRS and applied the variable return to scale (VRS) assumption, we were able to further decompose efficiency change into pure technical efficiency change (PECH) and scale efficiency change (SECH). The PECH measures the proximity of REIT to the frontier, devoid of scale effects. The SECH, on the other hand, captures the deviations between the VRS and CRS technology at observed inputs, indicating the changes in efficiency due to movement toward or away from the frontier. In essences, TFPCH = 
Nor Nazihah Chuweni, Ihsan Isik \& Andrea Blake

Total factor productivity change in the REIT industry: The case of Malaysian REIT during and post global financial crisis

TECHCH $\times$ EFFCH and EFFCH = PECH $\times$ SECH. Further discussion on the MPI follows.

\section{Data and Empirical Design}

We collected our data from annual reports of M-REITs, Thomson Reuters Datastream and Osiris via Bureau Van Dijk for the years 2007 to 2015. Following previous works on REIT efficiency and productivity, total asset (Y1) were selected as output variables, while interest expense (X1), property operating expense (X2) and administrative and management expense (X3) as the input variables (Anderson, Fok, Springer, \& Webb, 2002; Chuweni et al., 2017; Topuz et al., 2005; Topuz \& Isik, 2009). Table 1 displays the summary of statistics of data used.

Table 1: Descriptive statistics for inputs and output variables

\begin{tabular}{lcccc}
\hline Y1: Total & $\begin{array}{c}\text { X1: Interest } \\
\text { Asset } \\
\text { (RM million) }\end{array}$ & $\begin{array}{c}\text { X2: Property } \\
\text { Operating } \\
\text { (RM million) }\end{array}$ & $\begin{array}{c}\text { X3: Administrative \& } \\
\text { Management } \\
\text { (RM million) }\end{array}$ & $\begin{array}{c}\text { Expense } \\
\text { (RM million) }\end{array}$ \\
\hline Min & 171.151 & 0.21638 & 1.065 & 0.9215 \\
Mean & $1,700.716$ & 21.378 & 26.692 & 11.963 \\
Max & $9,568.582$ & 100.361 & 122.397 & 76.534 \\
S.D & $1,779.108$ & 20.710 & 32.044 & 15.939 \\
\hline Source: M-REITs' annual reports & & &
\end{tabular}

\section{RESULTS AND DISCUSSIONS}

In this section, we analyse the performance of M-REITs during (2007-2009) and after the crisis (2010-2015). With reference to Table 2, the Malmquist Productivity Index results indicate that the Malaysian REIT industry has an average geometric mean of TFPCH regress of $14.91 \%$. The result of TFPCH of M-REITs seems to imply that M-REITs exhibited TFPCH regress during all years mainly attributed by $33.40 \%$ of TECHCH regress. Our findings were corroborated with the findings by Topuz and Isik (2009) where REIT has failed to improve technically but applied significant effort to catch up with the best practice by depending on aggressive growth strategies. The decomposition of EFFCH into PECH and SECH indicate that the main sources for M-REITs' EFFCH is due to pure technical efficiency (PECH) rather than scale efficiency. The results suggest that M-REITs are more managerial efficient in controlling the operational expenses but not operating at the optimum scale of operations. Table 3 depicts the summary of geometric means of Malmquist Productivity Index for each Malaysian REIT for the period under study. The results indicatethat 2 REITs have exhibited TFP progress namely REIT 4 and REIT 12 with an increase of $2.66 \%$ and $2.36 \%$ for TFPCH progress respectively. The sources for TFPCH growth could mainly be attributed to the EFF increase rather than technological change. 
PLANNING MALAYSIA

Journal of the Malaysia Institute of Planners (2019)

Table 2: Summary of Malmquist Productivity Index of Malaysian REITs (2007-2015)

\begin{tabular}{cccccc}
\hline & EFFCH & TECHCH & PECH & SECH & TFPCH \\
\hline $2007-2008$ & 1.4640 & 0.4950 & 1.3880 & 1.0550 & 0.7240 \\
$2008-2009$ & 1.1530 & 0.7800 & 1.1120 & 1.0370 & 0.8990 \\
$2009-2010$ & 2.1850 & 0.3470 & 1.3040 & 1.6750 & 0.7570 \\
$2010-2011$ & 0.9090 & 1.0210 & 0.9000 & 1.0100 & 0.9280 \\
$2011-2012$ & 2.6040 & 0.2790 & 1.6520 & 1.5770 & 0.7270 \\
$2012-2013$ & 1.4540 & 0.6070 & 1.3160 & 1.1040 & 0.8830 \\
$2013-2014$ & 1.3740 & 0.6890 & 1.2400 & 1.1080 & 0.9470 \\
$2014-2015$ & 0.8490 & 1.1100 & 0.9380 & 0.9050 & 0.9420 \\
Mean & & & & & \\
$2007-2009$ & 1.3085 & 0.6375 & 1.2500 & 1.0460 & 0.8115 \\
$2010-2015$ & 1.5625 & 0.6755 & 1.2250 & 1.2298 & 0.8640 \\
$\mathbf{2 0 0 7 - 2 0 1 5}$ & $\mathbf{1 . 4 9 9 0}$ & $\mathbf{0 . 6 6 6 0}$ & $\mathbf{1 . 2 3 1 3}$ & $\mathbf{1 . 1 8 3 9}$ & $\mathbf{0 . 8 5 0 9}$ \\
\hline
\end{tabular}

Table 3: Summary of MPI for Malaysian REIT 2007-2015 (by firm)

\begin{tabular}{lccccc}
\hline REIT/ Index & EFFCH & TECHCH & PECH & SECH & TFP \\
\hline REIT 1 & 1.2563 & 0.6007 & 1.2247 & 1.0260 & 0.7546 \\
REIT 2 & 1.3321 & 0.6996 & 1.1549 & 1.1534 & 0.9319 \\
REIT 3 & 1.7545 & 0.5529 & 1.3867 & 1.2651 & 0.9702 \\
REIT 4 & 1.8134 & 0.5660 & 1.3549 & 1.3381 & $1.0266^{*}$ \\
REIT 5 & 1.2246 & 0.7195 & 1.0797 & 1.1344 & 0.8810 \\
REIT 6 & 1.7294 & 0.5537 & 1.3843 & 1.2493 & 0.9579 \\
REIT 7 & 1.6382 & 0.5131 & 1.3611 & 1.2037 & 0.8407 \\
REIT 8 & 1.6063 & 0.5817 & 1.3168 & 1.2197 & 0.9344 \\
REIT 9 & 0.9733 & 0.8682 & 0.9587 & 1.0153 & 0.8450 \\
REIT 10 & 1.5345 & 0.6256 & 1.0000 & 1.5345 & 0.9600 \\
REIT 11 & 1.0193 & 0.5696 & 1.0000 & 1.0193 & 0.5807 \\
REIT 12 & 1.7824 & 0.5743 & 1.3560 & 1.3147 & $1.0236 *$ \\
REIT 13 & 1.5153 & 0.5973 & 1.7741 & 0.8541 & 0.9043 \\
REIT 14 & 1.0726 & 0.5170 & 1.1353 & 0.9450 & 0.5539 \\
REIT 15 & 0.9434 & 0.6791 & 1.0416 & 0.9055 & 0.6405 \\
REIT 16 & 1.0000 & 0.8369 & 1.0000 & 1.0000 & 0.8369 \\
REIT 17 & 1.0624 & 0.5851 & 0.9999 & 1.0626 & 0.6217 \\
\hline
\end{tabular}

Note: grey shades indicate M-REITs with TFPCH growth; EFFCH = Technical Efficiency Change; TECHCH $=$ Technological Change; $\mathrm{PECH}=$ Pure Technical Efficiency Change; $\mathrm{SECH}=$ Scale Efficiency Change; $\mathrm{TFPCH}=$ Total Factor Productivity Change.

Development in the Number of Malaysian REITs with Productivity Gain (Loss) or Efficiency Increase (Decrease)

Analysis based on the number of M-REITs with productivity gain (loss) or efficiency increase (decrease) was performed to address the issue of possible outliers. The results are tabulated in Panel A-C in Table 4. As the results in Panel A of Table 4 indicate, $63 \%$ M-REITs have experienced productivity loss for the period of 2007-2015. The number of M-REITs with TFPCH loss is seen to 
Nor Nazihah Chuweni, Ihsan Isik \& Andrea Blake

Total factor productivity change in the REIT industry: The case of Malaysian REIT during and post global financial crisis

decrease from $63.18 \%$ during financial crisis to $60.86 \%$ for $2010-2015$. Similar trend could also be observed from the number of M-REITs which experienced technological regress has decreased from $86.37 \%$ for $2007-2009$ to $74.85 \%$ in 2009-2015. It is also interesting to note there is a mix result of EFFCH increase (decrease) and productivity stagnant of M-REITs for the period under study.

\section{Sources of Productivity of M-REITs}

Table 5 represents the sources of productivity (growth) and efficiency increase (decrease) for M-REITs during the period of 20017-2015. Table 5 is the decomposition from the results in Table 4. For instance, in 2007-2008, of the majority of $90 \%$ of M-REITs which have experienced productivity loss as depicted in Table 5 could mainly be attributed by technological regress, while $10 \%$ of M-REITs which have experienced productivity growth were the result of efficiency increase. Apart from that, the results exhibit productivity regress due to technological regress rather than efficiency change for Malaysian REITs. The results are also consistent with other market sectors since Md Saad, Abd. Majid, Kassim, Hamid and Yusof (2010) also found that on average, Malaysian unit trust which experienced productivity regress were likely due to technological regress. Therefore, it is important to investigate on the reasons for this technological regress which have adverse impact on Malaysian REIT productivity.

One possible reason for this technological regress is likely due to the income distribution requirement Topuz (2002). Under the Malaysian REIT guideline (Securities Commission Malaysia, 2012), REIT managers need to distribute 90\% of their taxable income and therefore could not retain their earning and reinvest their income for the following year. Since the funding for purchasing new assets are lacking, the managers need to have access to external capital. Raising the fund through debt and equity are costly than the retained earnings, resulting to a higher cost of capital. This higher cost of capital might be the reason for the technological regress throughout the studied period. Further investigation into the input revealed that the increase in total expenses are likely due to the managers controllable expenses (the combination of the administrative/ management and property operating expenses) rather than the market driven expenses (interest expenses). The findings validate earlier efficiency results when the dominant sources for technical inefficiency are due to pure technical inefficiency (managerial inefficiency). 
PLANNING MALAYSIA

Journal of the Malaysia Institute of Planners (2019)

Table 4: Developments in the number of M-REITs with productivity gain (loss) or efficiency increase (decrease) ${ }^{i}$

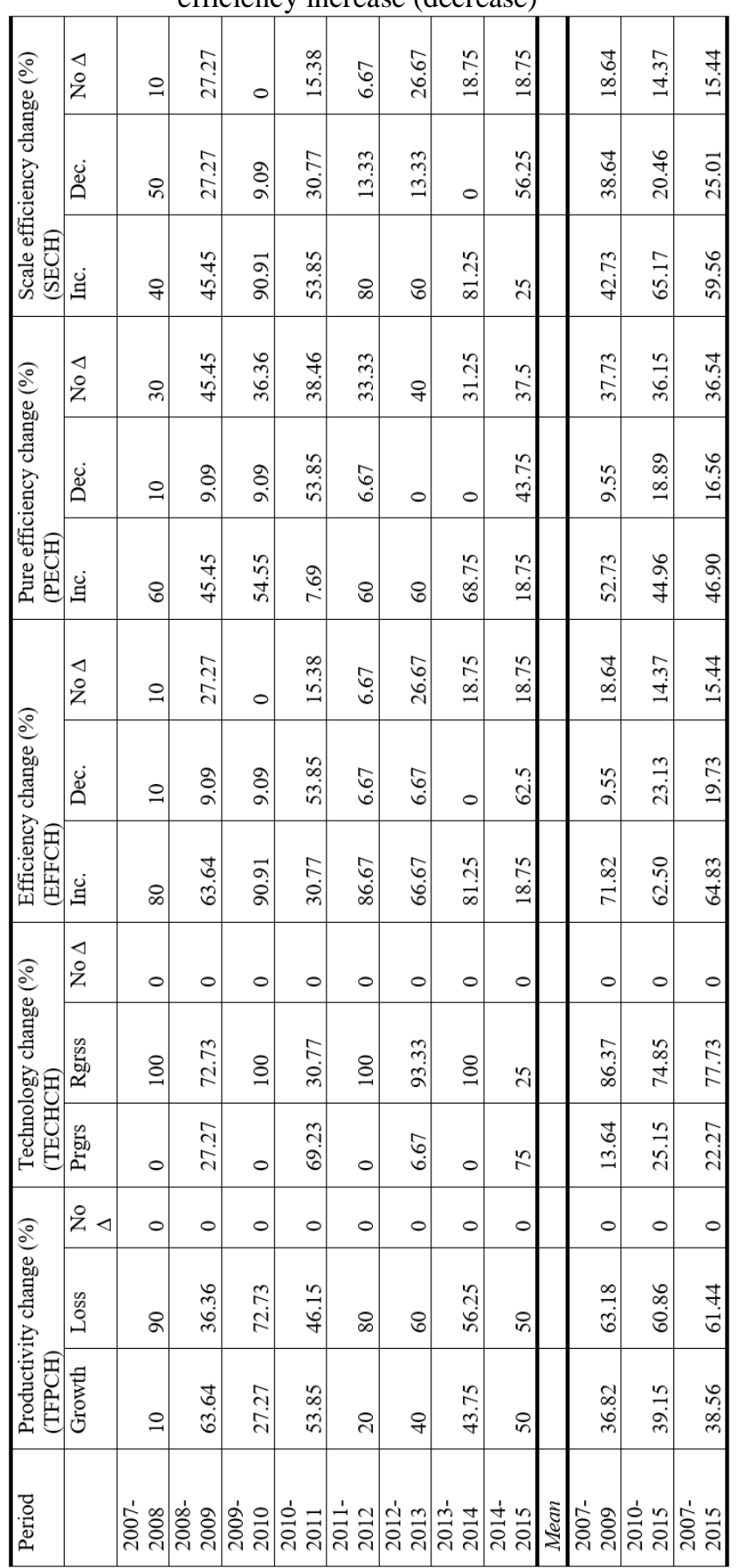


Nor Nazihah Chuweni, Ihsan Isik \& Andrea Blake

Total factor productivity change in the REIT industry: The case of Malaysian REIT during and post global financial crisis

Table 5: Sources of productivity of M-REITs ii

\begin{tabular}{|c|c|c|c|c|c|c|c|c|c|c|c|}
\hline \multicolumn{2}{|l|}{ 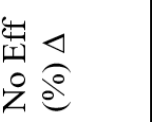 } & \begin{tabular}{l}
8 \\
\hdashline \\
0 \\
-
\end{tabular} & $\mid \begin{array}{c}\hat{N} \\
\stackrel{2}{N}\end{array}$ & $\begin{array}{l}8 \\
\vdots \\
\vdots\end{array}$ & $\begin{array}{cc}\infty \\
n \\
n \\
-1 & 0 \\
& 0\end{array}$ & 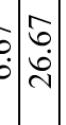 & $\left|\begin{array}{l}n \\
\stackrel{0}{\infty} \\
\infty\end{array}\right|$ & $\begin{array}{l}n \\
\stackrel{0}{\infty} \\
-1\end{array}$ & $\begin{array}{l}\mathbf{J} \\
\infty \\
\infty \\
-1\end{array}$ & $\stackrel{\tilde{m}}{\dot{I}}$ & $\begin{array}{l}\text { 寸 } \\
\stackrel{2}{2}\end{array}$ \\
\hline 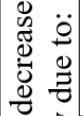 & 稆 它 & $\begin{array}{l}8 \\
0 \\
0 \\
0\end{array}$ & $\begin{array}{l}8 \\
0 \\
0\end{array}$ & $\begin{array}{l}a \\
\partial \\
a\end{array}$ & $\begin{array}{ll}\hat{\gamma} & 0 \\
\dot{\rho} & 0 \\
0\end{array}$ & \begin{tabular}{l|l|}
0 & 0 \\
0 & 0 \\
$\dot{0}$
\end{tabular} & $\begin{array}{l}8 \\
\\
\end{array}$ & 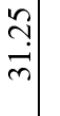 & $\begin{array}{l}8 \\
\text { in } \\
\end{array}$ & $\begin{array}{l}\hat{0} \\
\dot{I}\end{array}$ & 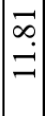 \\
\hline 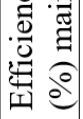 & 四 & $\mid \begin{array}{l}8 \\
\dot{0} \\
\end{array}$ & $\begin{array}{l}2 \\
0 \\
a\end{array}$ & \begin{tabular}{l|l}
8 & \\
$\vdots$ & \\
\hdashline
\end{tabular} & $\mid \begin{array}{ll}\infty & 8 \\
\dot{\nu} & 0 \\
\text { ஸे }\end{array}$ & \begin{tabular}{ll|l|} 
\\
\end{tabular} & $\begin{array}{l}8 \\
0 \\
0\end{array}$ & & $\mid \begin{array}{l}n \\
\tilde{r} \\
\dot{\gamma}\end{array}$ & & $\stackrel{n}{\Omega}$ \\
\hline 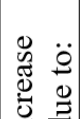 & 晥 & 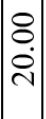 & $\mid \begin{array}{c}\infty \\
\infty \\
-\end{array}$ & $\begin{array}{l}\stackrel{2}{a} \\
\stackrel{\sim}{\sim}\end{array}$ & \begin{tabular}{l|l}
$\hat{n}$ & $m$ \\
$\dot{0}$ & $m$ \\
$m$ & $n$
\end{tabular} & 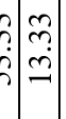 & \begin{tabular}{c}
$n$ \\
\\
\hdashline \\
\end{tabular} & ণุ. & $\mid \begin{array}{l}8 \\
\stackrel{0}{0}\end{array}$ & $\begin{array}{l}\vec{b} \\
\dot{+}\end{array}$ & $\begin{array}{l}\stackrel{n}{r} \\
\dot{0} \\
m\end{array}$ \\
\hline 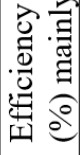 & 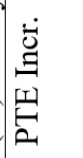 & \begin{tabular}{l}
8 \\
\hdashline \\
\hdashline \\
0
\end{tabular} & 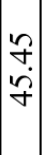 & $\mid$\begin{tabular}{c|}
$\infty$ \\
$\infty$ \\
$\infty$ \\
$-\infty$
\end{tabular} & \begin{tabular}{l|c}
8 & $m$ \\
0 & $m$ \\
\end{tabular} & 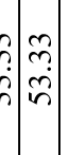 & $\mid \begin{array}{l}8 \\
8 \\
0 \\
i n\end{array}$ & $\begin{array}{l}0 \\
n \\
\\
\end{array}$ & $\left|\begin{array}{l}m \\
\stackrel{2}{n} \\
\sim\end{array}\right|$ & $\begin{array}{l}\infty \\
\stackrel{\sim}{N}\end{array}$ & $\begin{array}{l}0 \\
\stackrel{0}{1} \\
\dot{m}\end{array}$ \\
\hline 号宫 & $\stackrel{o}{d} \triangleleft^{0}$ & 0 & 0 & 0 & 100 & 0 & 0 & 0 & 0 & 0 & 0 \\
\hline 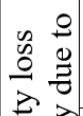 & 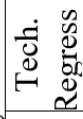 & ○! & ָे & 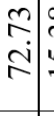 & $\mid$\begin{tabular}{l|l}
$\infty$ & 8 \\
$n$ \\
$n$ \\
& $\infty$ \\
\end{tabular} & 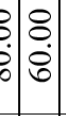 & 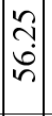 & ণุ. & $\left|\begin{array}{c}\mathbb{U} \\
\infty \\
\infty \\
n\end{array}\right|$ & $\begin{array}{l}f \\
\dot{\infty} \\
\dot{f}\end{array}$ & $\begin{array}{l}\stackrel{2}{\Omega} \\
\text { ஸे }\end{array}$ \\
\hline $\begin{array}{ll} & 0 \\
0 & 0 \\
0 & 0 \\
0 & 0 \\
0 & 0\end{array}$ & 出 & $\begin{array}{l}8 \\
0 \\
0\end{array}$ & $\begin{array}{l}0 \\
0 \\
a\end{array}$ & \begin{tabular}{c}
8 \\
0 \\
\hdashline
\end{tabular} & $\mid$\begin{tabular}{c|c}
$\hat{1}$ & 8 \\
$\dot{0}$ & 0 \\
\end{tabular} & \begin{tabular}{ll|l} 
\\
\end{tabular} & $\begin{array}{l}8 \\
0 \\
0\end{array}$ & $\begin{array}{l}n \\
\stackrel{n}{\sigma} \\
\dot{\gamma}\end{array}$ & $\left|\begin{array}{l}n \\
n \\
\dot{\gamma}\end{array}\right|$ & 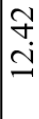 & 号 \\
\hline 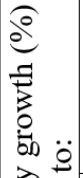 & 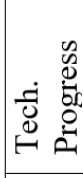 & ○ & $\left|\begin{array}{c}\infty \\
0 \\
\infty \\
-1\end{array}\right|$ & $\stackrel{8}{8}$ & $\mid$\begin{tabular}{l|l}
0 & 8 \\
+ \\
$\dot{0}$ \\
$m$ & 0 \\
$m$
\end{tabular} & 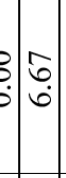 & $\begin{array}{l}8 \\
0 \\
0\end{array}$ & ñ. & $\mid \begin{array}{l}8 \\
0 \\
a\end{array}$ & $\stackrel{\hat{\vartheta}}{\vec{m}}$ & $\begin{array}{l}8 \\
0 \\
1 \\
1\end{array}$ \\
\hline 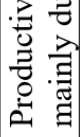 & 离 & 옹 & 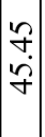 & त̂. & 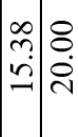 & 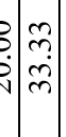 & $\mid \begin{array}{c}n \\
\stackrel{n}{r} \\
\dot{r} \\
\end{array}$ & $\begin{array}{l}0 \\
\\
\end{array}$ & $\left|\begin{array}{c}n \\
\stackrel{2}{\sim} \\
\end{array}\right|$ & $\begin{array}{l}\hat{n} \\
\\
\text { ñ }\end{array}$ & 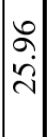 \\
\hline & & 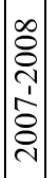 & 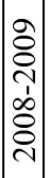 & 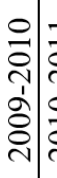 & 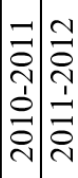 & 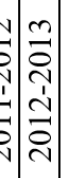 & 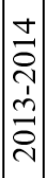 & 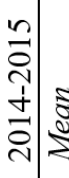 & 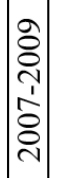 & 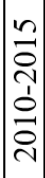 & 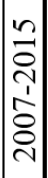 \\
\hline
\end{tabular}


PLANNING MALAYSIA

Journal of the Malaysia Institute of Planners (2019)

\section{CONCLUSION}

This study discusses productivity changes for the M-REITs using a non-parametric approach of Malmquist Productivity Index (MPI) of Data Envelopment Analysis (MPI-DEA) between 2007 and 2015. The methodology has allowed us to isolate the efforts to catch up to the frontier (EFFCH) from the frontier shift (TECHCH). Furthermore, Malmquist index has enabled us to explore the sources of efficiency change, whether there is a need in improvements in management practice $(\mathrm{PECH})$ or improvement towards optimal size (SECH). Our study was confined to Malaysian REITs listed in Bursa Malaysia between 2007 to 2015. This paper also aimed to fill a gap in the real estate efficiency and productivity through the establishment of recent evidence on the productivity changes of M-REITs. Our results suggested that the impact of the global financial crisis on the productivity, technology and efficiency of the M-REITs was dramatic. On average, M-REIT industry faced an $18.85 \%$ productivity loss, comprising $36.25 \%$ of technological regress and $30.85 \%$ of efficiency increase during 2007-2009 period, implying that the major source of productivity decline was shock to the REIT industry technology rather than an increase in efficiency.

On average, the M-REIT industry has faced $14.91 \%$ of productivity regress during 2007-2015 period, comprising $49.90 \%$ of efficiency increase and $33.40 \%$ technological regress. These decomposition of the productivity change index suggest that Malaysian REIT productivity changes were mainly due to efficiency change rather than technological change. One possible reason for this technological regress is likely due to the income distribution requirement in which the REIT managers could not retain their earning and reinvest their income for the following year. Since the funding for purchasing new assets are lacking, the REIT managers need to have access to external capital. Raising the fund through debt and equity are costly than the retained earnings, resulting in a higher cost of capital.

We have also explored the sources of efficiency change when the results indicate that the main sources for efficiency change is likely due to management practice (pure technical efficiency change). This establishes the need for improvement in management practice rather than scale adjustment.

Empirical findings from this study provide insight for the policy maker in attaining the optimum utilisation of resources, improvement in managerial skills and the optimum scale of operation for M-REITs. This helps to establish the need to facilitate sustainable competitiveness of M-REIT operations in the future. Moving forward, it is reasonable to expect that regulatory policy measures will be geared towards enhancing the efficiency and productivity of REIT operating in the Malaysian real estate investment industry, with the aim of intensifying the robustness and growth of the industry. A different approach to measuring REIT efficiency and productivity over a longer period for M-REITs will produce a more robust result. This includes estimating the efficiency and 
productivity using the bootstrap DEA and parametric approach, which falls outside the scope of the current study.

\section{ACKNOWLEDGEMENT}

The authors would like to acknowledge the sponsors and the anonymous referees for the feedback received in improving this research paper.

\section{REFERENCES}

Anderson, R. I., Fok, R., Springer, T., \& Webb, J. (2002). Technical efficiency and economies of scale: A non-parametric analysis of REIT operating efficiency. European Journal of Operational Research, 139, 598-612.

Angabini, A., \& Wasiuzzaman, S. (2011). Impact of the global financial crisis on the volatility of the Malaysian stock market. International Proceedings of Economics Development and Research Journal, 3, 79-84.

Chuweni, N. N., Eves, C., Hoang, V.-N., Isik, I., \& Hassan, M. K. (2017). How efficient are alternative financial institutions? An empirical investigation of Islamic REITs in Malaysia. Journal of Real Estate Literature, 25(1), 109-139.

Coelli, T. (1996). A guide to DEAP version 2.1: A data envelopment analysis (computer) program. CEPA Working Paper 96/08. Retrieved from http://www.une.edu.au/econometrics/cepa.htm

Fare, R., Grosskopf, S., \& Lovell, C. A. K. (1994). Production frontier. Cambridge: Cambridge University Press.

Grifell-Tatjé, E., \& Lovell, C. A. K. (1996). Deregulation and productivity decline: The case of Spanish savings banks. European Economic Review, 40, 1281-1303.

Isik, I., \& Topuz, J. C. (2017). Meet the "born efficient" financial institutions: Evidence from the boom years of US REITs. Quarterly Review of Economics and Finance, 66, 70-99.

Md Saad, N., Abd. Majid, M. S., Kassim, S., Hamid, Z., \& Yusof, R. M. (2010). A comparative analysis of the performance of conventional and Islamic unit trust companies in Malaysia. International Journal of Managerial Finance, 6(1), 2447.

Securities Commission Malaysia. (2012). Guidelines on real estate investment trusts. Securities Commission Malaysia.

Topuz, C. (2002). Efficiency and Performance of real estate investment trusts: An empirical examination (DBA thesis). Lousiana Tech University, Ann Arbor, USA.

Topuz, J. C., Darrat, A. F., \& Shelor, R. M. (2005). Technical, allocative and scale efficiencies of REITs: An empirical inquiry. Journal of Business Finance \& Accounting, 32(9 \& 10), 1961-1994.

Topuz, J. C., \& Isik, I. (2009). Structural changes, market growth and productivity gains of the US real estate investment trusts in the 1990s. Journal of Economics and Finance, 33, 288-315.

Topuz, J. C., \& Prather, L. J. (2007). Firm size and productivity: The case of REITs. Journal of Academy of Business and Economics, VII(1), 213-224. 
${ }^{\mathrm{i}}$ M-REITs are classified into the following categories: Productivity growth: TFPCH $>1$, productivity loss: TFPCH $<1$, productivity stagnant: TFPCH $=1$, Technological progress: TECHCH $>1$, Technological regress TECHCH $<1$, Technological stagnant $\mathrm{TECHCH}=1$, technical, pure technical and scale efficiency increase: EFFCH, PECH, SECH >1, technical, pure technical and scale efficiency decrease: EFFCH, PECH, SECH <1, No change in technical, pure technical and scale efficiency: EFFCH, $\mathrm{PECH}, \mathrm{SECH}=1$.

${ }^{i i}$ M-REITs are classified into the following categories: Productivity growth due to technological progress (efficiency increase): TFPCH $>1$ and TECHCH $>1$ and EFFCH (TFPCH $>1$, and $\mathrm{EFFCH}>1$ and TECHCH); productivity loss due to technological regress (efficiency decrease): TFPCH $<1$, TECHCH $<1$ and EFFCH (TFPCH $<1$, and EFFCH $<1$ and TECHCH); efficiency increase due to PTE increase (SE increase); EFFCH $>1$ and $\mathrm{PECH}>1$ and $\mathrm{SECH}(\mathrm{EFFCH}>1$ and $\mathrm{SECH}>1$ and $\mathrm{PECH}$; Efficiency decrease due to PTE decrease (SE decrease): $\mathrm{EFFCH}<1$, and $\mathrm{PECH}<1$ and $\mathrm{SECH}(\mathrm{EFFCH}<1$, and $\mathrm{SECH}<1$ and $\mathrm{PECH})$.

Received: $28^{\text {th }}$ October 2018. Accepted: $1^{\text {st }}$ March 2019 